\title{
The Frequency of Fire in East Texas Forests
}

David H. Jurney

Unknown

John Ippolito

Velicia Bergstrom

Follow this and additional works at: https://scholarworks.sfasu.edu/ita

Part of the American Material Culture Commons, Archaeological Anthropology Commons, Environmental Studies Commons, Other American Studies Commons, Other Arts and Humanities Commons, Other History of Art, Architecture, and Archaeology Commons, and the United States History Commons

Tell us how this article helped you.

This Article is brought to you for free and open access by the Center for Regional Heritage Research at SFA ScholarWorks. It has been accepted for inclusion in Index of Texas Archaeology: Open Access Gray Literature from the Lone Star State by an authorized editor of SFA ScholarWorks. For more information, please contact cdsscholarworks@sfasu.edu. 


\section{The Frequency of Fire in East Texas Forests}

Creative Commons License

(c) (i) (8)

This work is licensed under a Creative Commons Attribution-NonCommercial 4.0 International License 


\title{
THE FREQUENCY OF FIRE IN EAST TEXAS FORESTS
}

\author{
David H. Jurney, John Ippolito, and Velicia Bergstrom
}

The debate over the use of fire by Native Americans has been a lively one for many years. Did they or did they not set fires? If they did, how frequently and for what purpose? If not, did they take advantage of naturally occurring fires for the same purposes? If so, how frequently and to what intensity did those natural fires occur? These seem like relatively simple questions that should elicit focused, directed research that would, in turn, produce straightforward answers. In some parts of North America, this has indeed been the case. Ethnographic documentation, corroborated by archaeological research, has produced unequivocal evidence that the first Americans used fire extensively to manipulate the environment in which they lived.

This article examines early historic accounts of Native American use of fire in Texas, and the frequency of natural fires. These data are important not only to our understanding of the extent to which humans altered the landscape, but also how plant communities adapted to fires. Often, we interpret paleoenvironmental data to reflect climatic changes. However, we must also understand the factors that may have contributed to these changes in pollen sequences and soil formation processes.

\section{EARLY HISTORIC ACCOUNTS OF FIRE USE}

The following discussion presents excerpts from several early historic accounts of Indian use of fire. These are included here because of the widely scattered nature of the accounts. These accounts are by no means comprehensive, and more may exist; they do, however, indicate the behavior involved in fire use.

While traveling through what is now Texas in the early 16th century, Cabeza de Vaca observed:

Those from farther inland...go about with a firebrand, setting fire to the plants and timber so as to drive off the mosquitoes, and also to get lizards and similar things which they eat, to come out of the soil. In the same manner they kill deer, encircling them with fires, and they do it also to deprive the animals of pasture, compelling them to go for food where the Indians want (Hodge and Lewis I984:67; Fehrenbach 1968:23).

Cabeza de Vaca was somewhere on the Texas coast when he recorded this observation. His descriptions of the rivers and streams encountered by his party point to an area along the upper coast, near where the Brazos River flows into the Gulf of Mexico. It is not known what distance translates to "farther inland," or in what direction, making it difficult to attribute this observation to a particular group or groups of aboriginal inhabitants. Therein lies the intrinsic uncertainties, and the ultimate challenges, of defining Native American fire use and history in eastern Texas.

Fire was important to the Caddo Indians, as evidenced by the reverence afforded it in religious and ceremonial uses. The holiest of Caddoan temples were referred to as "fire temples" (Carter 1995; Swanton 1942), and it was believed that the fires that were kept in those temples were crucial to the survival of the people. Quoting from Espinosa, Swanton (1942:213) elaborates: 
They have especial superstitions in connection with fire and they worship it. There is a house set apart for this purpose where there is always a fire. They have appointed an old man whose duty it is to keep it up always. He is their chenesi or chief priest. They say that if it goes out everybody will die...Their fire or bonfire is always made of four very large, heavy logs which point toward the four principal directions. The wood is brought in small and kept in a pile outside. Here the old men gather for their consultations and war dances and when they need rain for their crops.

A similar account is presented by Morfi, quoted in Swanton (1942:214);

They also offer their adoration to fire. For this they have a house or temple where they perpetually keep a fire, and the care of this is entrusted solely to the Chenesi or High Priest, who himself and with the assistance of his subjects (subalternos) watches it with such zeal that it never goes out, as they are persuaded that if through any fatal accident this unfortunate event should occur, all the members of the nation would be immediately and irredeemably lost.

Carter (1995:124), speaking from the Caddo viewpoint on the importancc of fire to their culture, further explains:

The Hasinai defended their belief by saying that the missionarics' fire was different because it was made by striking it on against a rock. When Espinosa asked why the Hainai and Neche did not all leave their houses during buffalo time, when all the Nasoni and Nacogdoches left theirs, he was told it was so that the fire would not go out if wood failed. The Nasoni and Nacogdoches could leave their fire hanging up in their houses because they had a different kind of fire, which they made by rubbing two little sticks together. The fire of the Hainai and Neche could not be allowed to die since it came from their forefathers, kept alive from that time to this.

Interestingly, at the time of his observations about inland inhabitants setting fire to the plains and timber, Cabeza de Vaca had been in contact with coastal groups, Coahuiltecans and Karankawa, for an extended period. He wrote that in order to protect themselves from mosquitoes, "...we made fires, encircling the people with them, burning rotten and wet wood to produce smoke without flame..." (Hodge and Lewis 1984:67). It is also within this passage that another reference is made to use of fire in hunting deer by "...encircling them with fires. The pasturage is taken from the cattle by burning, that necessity may drive them to seek it in places where it is desired they should go" (Hodge and Lewis 1984:67). As it was customary for these groups to venture northward into the forests of East Texas during these seasonal hunts, it would seem logical that their behavior would not change, and that they would be setting fires in the forests for the same purposes.

It is possible that a tribal group known as the Bidai were the inland group described by Cabeza de Vaca. They occupied the lands along the lower Trinity River, in what are now Madison, Walker, Houston, Trinity, and Grimes counties, although they were seen as far east as the Sabine River and as far west as the Colorado River. Very little has been written about this group, and there have been no archeological excavations that can be directly tied to this group. In the most complete discussion of them available, Sjoberg (1951) has no mention of their use of fire other than for cooking.

Other entradas into eastern Texas by European explorers, most notably La Salle, specifically mention observing fire being used by Native Americans. La Salle and his 
company observed the practice used widely along the Gulf coastal plain and in the Mississippi River valley (Pyne 1982:75).

Henri Joutel's 1684-1687 journal mentions fires used by Indians more than seven times, from Matagorda Bay, to the Brazos River, to the Trinity and Neches rivers, and finally on the Red River (Foster 1998). On Matagorda Bay, Joutel reports: "Then I had the men camp as well as possible, having them make huts or sheds which they covered with grass from a nearby prairie which the Indians had earlier set fire" (Foster 1998:82). And, "a few days later [following an Indian encounter] we saw on the plains nearby a fire that spread and quickly burned the dry grass, drawing toward us. This compelled La Salle to have the grass around us quickly uprooted" (Foster 1998:92). At a place "called the Big Camp [Indian]...we found a lone Indian hut and saw that the Indians had set fire to the grass in the area" (Foster 1998:102).

Between the Colorado and Brazos rivers, Joutel recounted that "the bison were found in rather large numbers, which was surprising in the middle of several bands of people who roamed these areas. In addition the grass was burned and almost none had appeared. But these animals seem to delight in searching for the small sprigs of grass just beginning to sprout" (Foster 1998:174). Later in the Blackland Prairies, Joutel said:

Bison were not abundant in this area: the natives who had set fire to the grass had scattered them. Besides, Indians had hunted there for some time. Even though the grass was burned off, we saw a great many deer, but they took off in the distance. There were also many turkeys and other game. The scenery was very agreeable: mottes of trees from place to place, and, in locations where the grass had been bumed some time ago, it was beginning to green and looked like the wheat fields of France in April (Foster 1998:176).

In the hilly parts of central Washington County, La Salle's party encountered “...country |that]...was fine although at that time it was not in its full beauty as the Indians had recently set fire to the countryside, and much of it was black and covered with the ashes of burned grasses..." (Foster 1998:185).

Among the Cenis or Hasinai Caddo on the Neches River, possibly within the jurisdictional boundaries of the Davy Crockett National Forest, Joutel noted:

We laid down our baggage and put our horses out to pasture where there was very fine grass at that time, for the Indians had set fire during the fall. The grass had grown again very beautiful and green...The bottom lands between these hills were quite favorable; the land that the Indians cultivated produced very fine corn, beans and other similar crops, and very lovely grass grew everywhere...(Foster 1998:209, 234).

Similarly, De Soto a century and a half earlier observed the burning of the forests in other parts of the Southeast, by groups that culturally and linguistically are very similar to the Caddo. Considering that these explorations were undertaken with very large numbers of men and livestock, and considering the relative ease of passage of such large contingents over most of their route, we must assume that the forests were open and clear of underbrush. Frequently occurring fires, either set intentionally or as a result of natural forces, may have been one contributing factor to this openness.

Stephen Pyne, in his comprehensive study Fire in America: A Cultural History of Wildland and Rural Fire (1982), presents a far-reaching and thorough synthesis of fire use 
by Native Americans. His research reveals that the use of fire for clearing the forest, preparing agricultural fields, hunting, and defense in warfare, were traits that were practically universal across the continent (Pyne 1982:79). He cautions, however, against overly generalizing about the aboriginal use of fire:

...Fire practices were to some extent circumscribed by environmental constraints. Even more damaging to a simple picture of homogeneity is the recognition that tribes underwent migrations, experienced internal evolutions, and were forcibly dislocated. Their relationship to the land was thus a constantly changing one...(Pyne 1982:78).

Pyne (1982:79) continues, by describing fire as "...predominantly local, though the multiplication of local effects could produce surprisingly extensive cumulative results." $\mathrm{He}$ concludes:

The modification of the American continent by fire at the hands of Asian immigrants was the result of repeated, controlled surface burns on a cycle of one to three years, broken by occasional holocausts from escape fire and periodic conflagration during times of drought (Pyne 1982:79).

In his cultural history of the Neches River valley, Thad Sitton draws heavily on Pyne's work in his discussion of the use of fire by the Native Americans living in the region. Sitton (1995:26-27) presents a picture of:

...uplands that were the domain of fire. Fuel was abundant in the form of grass and pine needles. Pine needle fall was heavy, and the grass accumulated in places because there were no native grazers except the occasional buffalo. In this environment, lightning from thunderstorms of late summer and early fall could ignite numerous fires. Once started, a natural fire might survive the rainfall and dews by smoldering for days in the resin-rich heartwood of pine snags and roots, then break out and run great distances after winds rose and humidity fell.

Following Pyne's hypothesis, Sitton (1995:241) maintains that fire was a basic tool to the Caddo and other groups, using it to clear stubble from cultivated fields; to eliminate fleas, ticks, and other vermin from around their villages; to curb undergrowth and open the woods for travel and hunting; and increasing the edge effect, thereby encouraging the growth of desirable plant foods and drawing preferred wildlife species, such as turkey, closer to their villages. Early settlers were told by the Native American inhabitants that they "...burned the woods in the fall and spring to eliminate ticks, fleas, snakes and other vermin from around their villages...and to make fire drives for game..." (Sitton 1995:29). These early settlers enthusiastically embraced this use of fire, as an open, savannh-like understory was ideal for the raising of livestock. Stockmen in East Texas from 1830-1950 followed this tradition of setting the woods on fire in late winter or early spring, in the process recycling nutrients and promoting the regrowth of new grass for their cattle (Sitton 1995:241). Sitton (1995:241) concludes that:

The open park-like stands of longleaf and other pines that Anglo-Americans found when they arrived in southeastern Texas...are thought to be a maninduced fire sub-climax within the general deciduous region of the eastern woodlands (Lay 1987)...When fire was kept out of the upland forests...they tended to change into mixed forests of pine and hardwood in which the latter dominated. 
There are few detailed observations of wildfires in Texas, particularly in the East Texas forests. One description is known from the Blackland Prairie/Post Oak fringe in southern Dallas County. In 1847 or 1848, John Billingsley (1885:214-215) provided these details that connect weather patterns and vegetation dynamics:

It was late in the fall of the year and a dense coat of grass from knee to waist high covered the prairie from river to river [Mountain Creek to the Trinity River]. Though calm all day we saw smoke boiling up away to the north. We supposed ten to fifteen miles away and late in the afternoon, I started to the timber for a load of wood and my father started to the field to fire around it. There was a road running on two sides and some furrows plowed around the balance but before he got to the proper place to begin and just as I got to the timber there came a puff from the north, then a few minutes calm. Then another rush of wind that made the timber bow and tremble, a regular blue norther had now saluted us not with sleet and snow but with a sweeping raging fire. I had begun to load my wood when the wind struck me and before I could get out of the bottom the fire was there but there was nothing to burn in the bottoms but leaves so I made my way out to the burnt prairie. The fire camc in a breast a mile wide roaring like a tomado, curling, surging, and catching fifty yards away and then on again with the speed of the wind. When I got home our fencing was all in a light blaze, the branch bluff and naked space around the house saved them but the fire went on, the creek and timbered bottom was now in its way.

The importance of this account lies in the combination of season of year, fuel, and weather. Since there was a major storm front moving in, it is likely that this was a lightning-caused natural fire. The late fall-early winter fire covered at least 15 miles (9600 acres), and probably was much larger. This gives an estimate of the extent of wildfire that did not undergo suppression by man. Also, the fire was jumping, or spotting, at least 150 feet and leaped roads, fields, and streams. Both prairie and hardwood forest burned. Given this combination of fuel and weather, lightning-caused wildfires can be expected to have covered large expanses of the pre-settlement landscape, and could have been unhindered by geographic features such as rivers and floodplain forests.

\section{NATURAL FIRE FREQUENCY}

The natural frequency of fire is rarely noted in historic accounts. Our best data are derived from the records of fire management organizations, dating primarily to the $20 \mathrm{th}$ century. Most natural fires appear to have been ignited from lightning strikes, but there are rare observations of spontaneous combustion in Texas' coastal marshes. Other sources include volcanic or meteoric activity, which has no recent occurrences in Texas. However, only lightning-caused fires have been systematically reported.

Direct records of fires, their causes, and the extent of the burn were first kept in Texas by the U.S. Forest Service as they were being suppressed on federal lands. Later, the Texas Forest Service began to keep systematic records on fires they suppressed on private lands or state property. These records are of variable quality, and with asynchronous periods of record. These data are unpublished, but are available in computerized format from the Texas Forest Service since 1975 and the U.S. Forest Service from 1916-1990. The U.S. Forest Service publishes national summaries by state, which are spreadsheets on file at some federal repositories, or available from the Fire and Aviation Management Office, Washington, D.C. Since many fires are suppressed by volunteer fire 
departments or private timber companies, and are unenumerated, these data may be used to determine a minimum estimate of the frequency of lightning fires.

The computerized spreadsheet for the entire United States was provided by the U.S. Forest Service, Fire and Aviation Management, Washington office. The tables listing absolute numbers of fires by origin were selected, and all totals for Texas were transcribed (Figure 1). From 1916-1921, only the U.S. Forest Service reported fires in Texas. From 1922-1990, federal and Texas Forest Service records were enumerated together. U.S. Forest Service records from 1991-present are not available at this time, and only the Texas Forest Service data are represented from 1991-1997.

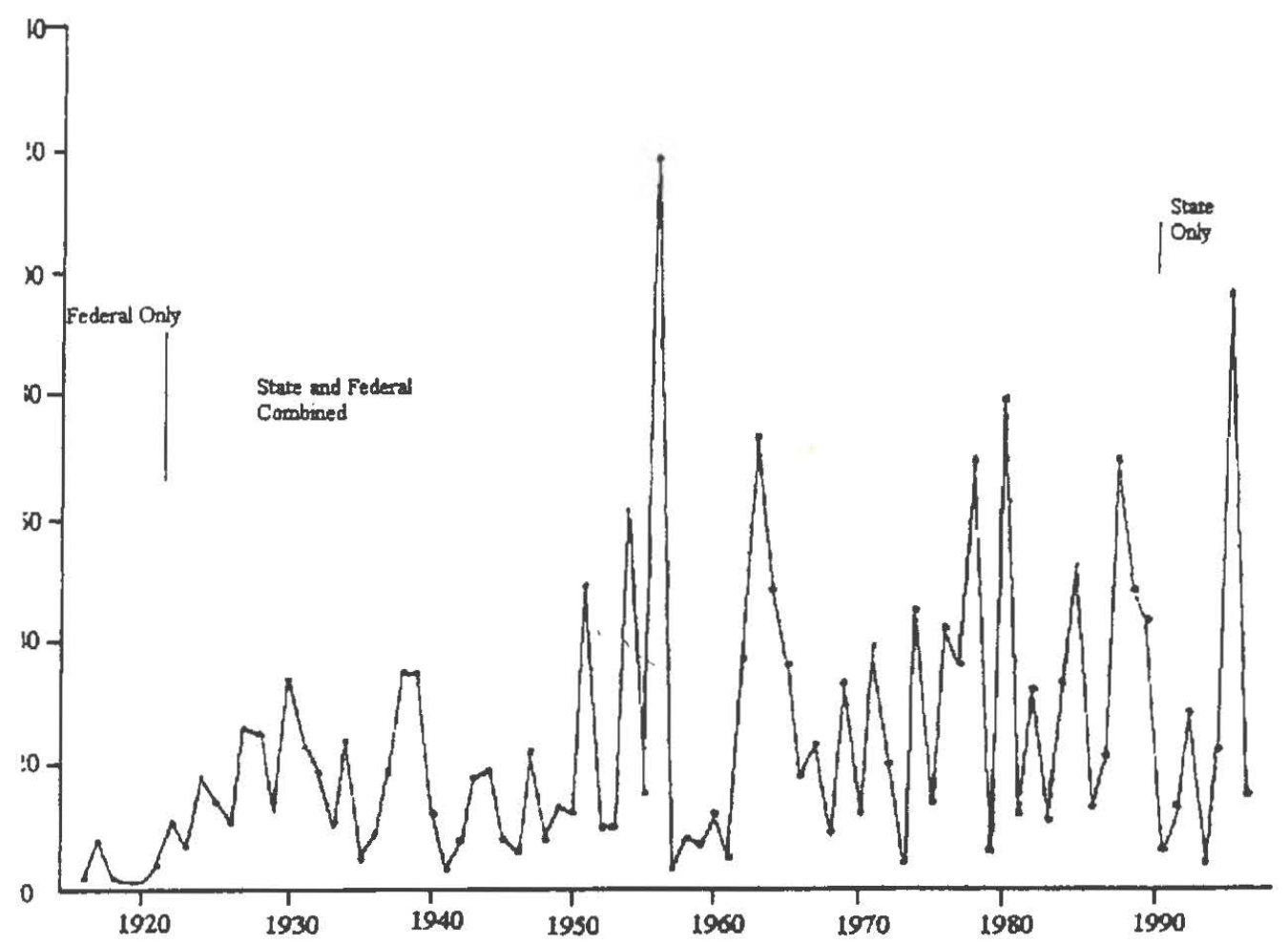

Figure 1. Number of lightning fires in Texas from 1916-1997.

A survey of the Texas Forest Service and U.S. Forest Service records was conducted to determine the geographic and temporal structure of the Texas records. There exists a wealth of data relating to cause and fire intensity levels that could not be effectively tapped at the present time. Instead, the date of occurrence, location, absolute number of fires, acreage of all fires, lightning-caused fires, and lightning-caused fire acreage were compiled from the many sources of information.

The U.S. Forest Service district fire atlases and computer printouts were also reviewed. All pertinent data relating to lightning-caused fires and total wildlife numbers were transcribed. These data are presented in graphic format in Figure 1. Tabular data are on file with the U.S. Forest Service. 
The absolutc number of lightning-caused fires appears to be the most robust statistic. The total number of fires represents the combined effects of natural and human influences.

\section{U.S. FOREST SERVICE ANNUAL SUMMARIES}

The annual fire data summaries obtained from the U.S. Forest Service, Fire and Aviation Management, Washington office, cover the period-of-record from 1916-1990 (see Figure 1). These data are summed for each state as a whole, occasionally recording whether the data were federal (all agencies) or state (all agencies and co-operators).

Lightning-caused fires were recorded every year for this 82 year period-of-record, with a mean average of 23.72 lightning fires per year. The years with above average lightning fire frequencies are ordered into three categories: extreme (96-118 lightning fires), frequent (61-79 lightining fires), and moderate (28-52 lightning fires). Extreme lightning fires include $1956(n=118)$ and $1996(n=96$, Texas Forest Service data only). Frequent lighnting fire years include $1980(n=79), 1963(n=73), 1978(n=69), 1988(n=69)$, and $1954(n=61)$. Moderate lightning fire years include $1985(n=52), 1951 \quad(n=49), 1964$ $(n=48), 1989(n=48), 1974 \quad(n=45), 1990 \quad(n=43), 1976(n=42), 1971 \quad(n=39), 1962$ $(n=37), 1965 \quad(n=36), 1977(n=36), 1938 \quad(n=35), 1939(n=35), 1930 \quad(n=34), 1969$ $(n=33), 1984(n=33), 1982(n=32)$, and $1993(n=28)$.

Prior to 1970, fire records were kept at the District level on the National Forests in Texas, and consist of large atlases with mapped locations of all wildland fires, occasional summary data sheets, and occasional atlases recording prescribed burns. The data consist of mapped fires and their probable causes by five-year groupings. Some are tabulated, providing numbers of fires by cause, number of fires by fire size, and month of the year. Again, only the total number of fires and lightning-caused fires were examined in this study.

Some of the atlases were curated by the Supervisor's Office in Lufkin, others are scattered among the District Offices, and some appear to have been lost. There are no comparable atlases for the Grasslands. For this study, all records in the Supervisor' Office were examined, including one volume from the Tenaha Ranger District (1955-1974), one volume from Sam Houston National Forest (1939-1963), one volume from the Angelina National Forest (1955-1974), and two volumes from Davy Crockett National Forest (19391978). In addition, duplicate and original atlases were examined from each of the four forests: two volumes from the Sabine National Forest (1949-1989), two volumes from the Davy Crockett National Forest (1955-1984), and two volumes from the Angelina National Forest (1939-1976). Volumes from the Sam Houston National Forest have not yet been cxamined. Computer files were used from 1970-1988 on the National Forests in Texas, but are available only in hard copy printout. These two computer printouts contain data from the four National Forests and two National Grasslands in Texas. The data include the date and exact geographic location, probable cause of ignition, area burned, fire intensity level, and cross-Labulated results.

Lightning-caused fires occurred every month of the year on the National Forests in Texas. The lightning fire season peaks from April to September. For the 1970-1989 period, all lightning-caused fires were recorded in the Forests; none were enumerated in the Grasslands. 


\section{CONCLUSIONS}

From the historic accounts, it is evident that Texas Indians actively used fire across the landscape. In fact, the Blackland Prairies may have been maintained and enlarged by human activities involving fire use. From the descriptions of Henri Joutel, fire altered the tall-grass prairie, and bison were attracted to the nutritious regrowth. Offensive and defensive uses of fire were also noted. Among the Hasinai Caddo, prairies were maintained, probably as sources for building materials such as thatch, as well as for forage for their newly acquired horses.

Natural fires produced by lightning are yearly occurrences in Texas. During periods of drought, the numbers of lightning fires increase radically, and could have burned extensive areas of East Texas. The most extensive areas of lightning-caused fires were in the longleaf pine dominated portions of southeastern Texas; however, lightning fires were also noted in the post oak savannah.

Historically, ecologists have assumed that plant and animal communities move through a series of succession stages toward a steady state, or climax, equilibrium. Since 1990, ecologists analyzing data from more intensive, long-term studies, have shifted from this perspective, requiring a total reconsideration of strategies of conservation and resource management (Stevens 1990; Oliver and Larson 1996:5).

The role of human and natural disturbances is scen to be increasingly important in determining forest structure and species composition. Fire is only one of many sources of disturbance. Fires which occur without suppression activities burn tens and hundreds of thousand acres (Frost 1993). Even tropical rain forests are susceptible, particularly during weather events such as drought or El Nino. Evidence of past fires has been found in all forest regions and all forest types (Stevens 1990).

In the southeastern U.S. coastal plain, fire return intervals have been determined for several forest types. Fires in the longleaf communities occur during the spring and fall on 2-3 year intervals. Fires in the sand pine community occur in the spring at 25-79 year intervals. Fires in the piedmont loblolly pine community occur at 10 year intervals (Oliver and Larson 1996:102-103). Thus, fire regimes compare to the frequencies of 2-10 years observed in the ponderosa pine-shrub communities of the southwestern U.S. Landscape analysis using a synthesis of fire records, physiography, historical vegetation records, and lightning ignition data, indicates fire return intervals less than 6 years for East Texas (Frost 1998). The original data presented in this article support and corroborate broader fire history data, with fire return intervals from 1.5 to 7 years in East Texas.

Evidence is increasing that forest stand structure has always fluctuated across given areas. Land management practices which promote setting aside large expanses where human activities are restricted or excluded rely on the steady state ecological theory. The assumption that all stand structure will "naturally" develop without disturbance is unfounded (Oliver and Larson 1996:397). Land management practices that are based on the dynamic theory of forest development which integrate disturbance, such as removal of timber and prescribed fire, are most productive in maintaining the full range of stand structure, landscape patterns, and species distributions across the landscape (Oliver and Larson 1996:397).

The implications of this study are that fires played an important role in the formation of the plant communities, and that Indians actively used fire to alter the East Texas landscape during the historic period. Long term climatic reconstructions should be 
evaluated in terms of fire ecology and the potential effects of fire in the alteration of plant communities.

\section{REFERENCES CITED}

Billingsley, J. B.

1885 A Trip to Texas. Texana 7:201-219.

Carter, C. E.

1995 Caddo Indians, Where We Come From. University of Oklahoma Press, Norman.

Fehrenbach, T. R.

1968 Lone Star: A History of Texas and the Texans. Collier Books, New York.

Foster, W. C. (editor)

1998 the La Salle Expedition to Texas: The Journal of Henri Joutel, 1684-1687. Texas State Historical Association, Austin.

Frost, C. C.

1993 Four Centuries of Changing Landscape Patterns in the Longleaf Pine Ecosystem. In Fire in Ecosystem Management: Shifting the Paradigm from Suppression to Prescription, edited by S. M. Hermann, pp. 70-81. Tall Timbers Fire Ecology Conference Proceedings, No. 18. Tall Timbers Research Station, Tallahassee, Florida.

1998 Presettlement Fire Frequency Regimes of the United States: A First Approximation. In Fire in Ecosystem Management: Shifting the Paradigm from Suppression to Prescription, edited by T. L. Pruden and L. A. Brennan. Tall Timbers Fire Ecology Conference Proceedings, No. 20. Tall Timbers Research Station, Tallahassee, Florida.

Hodge, F. W. and T. H. Lewis (editors)

1984 Spanish Explorers in the Southern United States, 1528-1543. Texas State Historical Association, Austin.

Lay, D. W.

1987 The Role of Fire in Forest Management. Paper presented at the Big Thicket Association Mecting, Beaumont.

Oliver, C. D. and B. C. Larson

1996 Forest Stand Dynamics. John Wiley and Sons, New York.

Pyne, S. J.

1982 Fire in America: A Cultural History of Wildland and Rural Fire. Princeton University Press, Princeton, New Jersey.

1983 Indian Fires. Natural History 92(2):6.

Sitton, T.

1995 Backwoodsmen: Stockmen and Hunters along a Big Thicket River Valley. University of Oklahoma Press, Norman. 
Sjoberg, A. F.

1951 The Bidai Indians of Southeastern Texas. Master's thesis, Department of Anthropology, The University of Texas at Austin.

Stevens, W. K.

1990 New Eye on Nature: The Real Constant is Eternal Turmoil. New York Times, Tuesday, July 31, 1990, B5-B6.

Swanton, J. R.

1942 Source Materialon the History and Ethnology of the Caddo Indians. Bulletin 132. Bureau of American Ethnology, Smithsonian Institution, Washington, D.C. 